\title{
THE EVOLUTION OF THE FEMALE CHARACTER: FROM FAIRY TALES TO THE FILM “BRAVE” - A STUDY IN COMPARATIVE LITERATURE
}

\author{
Luis Cardoso ${ }^{1 i}$, \\ Carolina Clérigo ${ }^{2}$ \\ ${ }^{1} \mathrm{PhD}$, Polytechnic Institute of Portalegre, \\ Centre for Comparative Studies - University of Lisbon, \\ Portugal \\ ${ }^{2}$ Basic Education (BA), \\ Polytechnic Institute of Portalegre, \\ Portugal
}

\begin{abstract}
:
This article aims to develop a comparative analysis between the evolution of the female character in fairy tales, and the film adaptation "Brave", launched in 2012. In this sense, we will evaluate the characteristics of the female character, over time, dividing princesses into three large groups. Regarding the cinematic narrative, we will analyze the main characteristics of the character Merida, and the plot of the scenes that makes the film surprising. The result of the analysis allows us to conclude that cinematography follows the evolution of society.
\end{abstract}

Keywords: comparative literature, children's literature, fairy tales, brave

\section{Introduction}

The concept of Comparative Literature is based on the comparison between two or more literary works and can also assume other types of comparison, as is the case, for example, the analysis of a literary narrative and its adaptation to the level of cinematography. The comparison makes it possible to assess the differences and similarities of what is being analyzed, and should not make judges of value, as the comparison is a means and not an end. According to Carvalhal, "It can be said, then, that the comparative literature compares not by the procedure itself, but because, as an analytical and interpretative resource (...) In summary, comparison, even in comparative studies, is a means, not an end " (Carvalhal, 2006, p.7). The term Comparative Literature has been debated by several authors and according to Guyard "Compared literature is the history of international literary relations. The comparator places himself at the borders, linguistic or national, and exhausts the changes in themes, ideas, books or feelings between two or several works of literature" (1951, cit. By Coutinho, 2006, p.42). Similarly, Remak states:

i Correspondence: email lmcardoso@ipportalegre.pt 
"Comparative literature is the study of literature beyond the borders of a specific country and the study of the relationships between literature on the one hand, and other areas of knowledge and belief, such as the arts, philosophy, history, social sciences, religion, etc., on the other side. In short, it is the comparison of one literature with another or others, and the comparison of literature with other spheres of human expression." (1961, cit. By Coutinho, 2006, p.44)

In this sense, Comparative Literature does not limit itself to comparing, within borders, but also confronts national literature with international literature. As we know, Comparative Literature refers to the comparison of works, either by comparing two literary works, or, for example, between a literary work and a cinematic narrative. Children's Literature is one of the resources that Comparative Literature uses for their studies because it is through the different stories that are part of the world of Children's Literature that comparators can carry out various studies. The first contact with Children's Literature is usually, through fairy tales, stories of princesses and princes with a happy ending. Authors like Perrault and the Grimm brothers have gained tremendous consideration and have become major names in this genre. According to Gomes "The magical kingdoms, territories of dream and fantasy, belong to stories of a common domain called fairy tales. Not all of these stories have fairies, but there are always spells, magic help, enchantments or some kind of fantasy element" (2000, cit. By Breder, 2013, p. 27). Fairy tales, appeared some centuries ago, being popular and reaching different cultures. No one does not remember one of these stories, which are part of their childhood, adolescence or even adult life. Due to their characteristics, fairy tales immediately fascinate the reader and capture their attention, through their linguistic simplicity and the existence of magic and enchantments. They address themes related to society, family, power, death, love and hate. These stories, when told to younger readers, immediately manage to associate the story with fairy tales, since its beginning always begins with "Once upon a time" and the end with "And they lived happily ever after". Initially, as stated by Pihel (2013), fairy tales were transmitted by the oral route, from generation to generation. Fairy tales were intended for adult people only since they covered content about adultery, incest, cannibalism, revenge and death. In the middle of the century. In the 17th century, fairy tales began to be aimed at children. Fairy tales are considered one of the ways of transmitting values and teachings for life, having a pedagogical character. The stories belonging to fairy tales have evolved as society evolved, that is, in each different era, they portray social relationships and different ways of living (Maia \& Maia, 2015). Several authors believe that fairy tales have important elements to help children deal with the most diverse personal problems, this does not happen with the most recent children's stories, where there is a concern of not exposing the child to conflicts and dilemmas. As Bettelheim states:

"The fairy tale is oriented towards the future and guides the child - in terms that he can understand in both his unconscious and conscious mind - to abandon his desires for child dependence and achieve a more satisfactorily independent existence." (2002, cit. By Breder, 2013, p.21)

Fairy tales have always inspired filmmakers. The existence of film adaptations has become more and more frequent. In this sense, the Disney studios, through their technical capacity and 
all the surrounding magic, can translate many fairy tales that we know to cinema screens and television screens. As Breder says, "The animation classics at Walt Disney Studios have found an infallible formula for achieving public success: they combine the enchantment of technique with captivating stories" and, "In addition to using this "magic" of animation, most of the studio's films are adaptations or reinterpretations of more or less successful stories" (Breder, 2013, p.20). In agreement with Aguiar \& Barros:

"Disney is known for revealing a charm that engages people in the world of magic it engenders, blending reality and fiction in a surprisingly subtle way. Besides, his cinematographic productions elevate the imaginary, rekindling the antagonism between good and evil, with a happy ending that regenerates dreams and the possibility of making them real." (Aguiar \& Barros, 2015, p.1).

Filmadaptation consists of adapting a literary work to cinema screens, but on the other hand, as stated by Freire "Film adaptation is not always concerned with exposing concepts that already exist in a given written work; often, it can express new values and, consequently, be as or more interesting than the text that inspired it" (Freire, 2008, p.180). Like Comparative Literature, film adaptation points to the study between two points of view, it is important to emphasize that film adaptation is different from literary work, each of these works having their similarities and differences. In this way, we conclude that Comparative Literature is a very vast field, which allows the study with a film narrative. In this article, we will analyze the characteristics of the female character, which we find in fairy tales, and later, we will analyze the film "Brave", highlighting the similarities and differences, of the character "Merida", concerning the traditional female character.

\section{The traditional female character}

Children's Literature is a very vast field, and a large part of his works are related to fairy tales. The Jacob and Wilhelm Grimm brothers are considered figures of excellence in terms of Children's Literature since the popular stories collected by them were incorporated into fairy tales, as stated by Guerreiro "(...) It was the Grimm brothers who dedicated them children for their magical and wonderful theme. Thus, these two universes merged: the popular and the childlike (...) (Guerreiro, 2013, p.5). Children's literature and fairy tales are, in fact, very important for the child's development. On the one hand, Children's Literature encourages children's learning, they manage to develop their writing and reading skills, but on the other hand, through fantasy and imagination, the child creates reference schemes for a better understanding of the world, and yet contributes to the development of its personality. According to Silva \& Figueiredo:

"(...) there are a series of attitudes, behaviours and ideals that developed in the collective unconscious from symbolic images from fairy tales" (Silva \& Figueiredo, 2016, p.3).

"It is rare to find a girl who has never played the role of a princess, with her beautiful dresses, waiting for her love, since they are part of her childhood imagination. In a society in which women 
are constantly exposed to an image of an ideal of beauty to follow, the princesses we find in fairy tales are the first example of an image to be followed." (Breder, 2013)

Female representation has been gaining enormous prominence since it follows the changes in society, that is, it is the result of changes in the context and the public. Over time, women have been gaining attributes and acquiring a new social position, allowing them a greater diversity of opportunities, giving access to possibilities that previously had no contact whatsoever (Fossatti, 2009). According to Lima, Antunes \& Pereira "If the protagonists of Disney's princess films are being portrayed more independently and strongly, this is the result of changes in the context and the audience (...)" (Lima, Antunes \& Pereira, 2018, p.5). Before analyzing and understanding how female representation has evolved over the years, it is necessary to understand the meaning of representation and what it means. The word represents, according to Hall, means "to describe, make similarity, rescue the imagination or replace" (1997, cit. By Lima, Antunes \& Pereira, 2018, p.3). While Vera França states that representations "can be taken as a synonym for signs, images, forms or content of thought, the representational activity of individuals, set of ideas developed by a society" (1997, cit. By Lima, Antunes \& Pereira, 2018, p. 4). In this sense, and as stated by Lima, Antunes \& Pereira:

"The transformation process of Disney's female protagonists, in this way, is part of a feedback system, in which the questioning about the figure of the woman is absorbed by the entertainment industry from society at the same time that the industry itself is an influencing agent. of this medium." (Lima, Antunes \& Pereira, 2018, p.4)

As already mentioned, most of the narratives used for Disney creations come from the adaptation of fairy tales. The stories that are portrayed on the big screens at Disney, based on these fairy tales, are part of society's discourses and are representations of concepts that are part of the imaginary (Silva, 2016). As Silva says, "Walt Disney Studios and fairy tales are intertwined, because most of the film production of this company aims to retell stories based on princesses, witches, orphaned children, princes, in short, characters essentially from fairy tales" (Silva, 2016, p.57). The traditional female representations that we can find, both in fairy tales and in Disney productions, are princesses. The female representation has changed over time, due to the influence of the environment and its evolution. As Fossatti states:

"The feminine story is driven by a range of transformations. In many ways, the woman was introduced to the public, but it is through the status of a princess that she found herself made present in the first animated feature film and in a series of others that followed." (Fossatti, 2009, p.6)

From the first release of the film "Snow White and the Seven Dwarfs", in 1937, to the most recent, released in 2019, "Frozen 2 - The Kingdom of Ice", that the representation of the princess has changed. Fossati, considers that the film "Snow White and the seven dwarfs" (Disney, 1937), initiated a sequence of animated film productions whose protagonists are marked by the status of 
princesses" (Fossatti, 2009, p.1). According to Breder, "Of the 52 feature films, 21 are based on books, eight on fairy tales, four on short stories, three on legends or myths, two on North American folklore stories and one on a real character, the indigenous Pocahontas" (Breder, 2010, p. 20). To understand the evolutionary process of female representation over time, we quote Lopes (2015), who divided the princesses into three categories, that is, classic, rebellious and contemporary princesses. We will analyze each of these groups, pointing out their characteristics. Within the category of the classic princess, between the years 1937 to 1959, we can include Snow White, Cinderella and Aurora. These princesses are characterized for being beautiful, passive, kind, tender, delicate, gentle, affable, fragile, naive and do not realize the existence of any kind of danger around them, submitting to any order. They dream of meeting their prince charming and correspond to the stereotype of fairies in the home, that is, they are seen only to take care of domestic chores and their children and maintain a very close connection with nature, as stated by Both "(...) based on wife-mother-housewife profile, whose only objectives are to meet the prince charming and family care." (Both, 2017, p.30). Snow White is protected by the seven dwarfs, Cinderella is protected by her fairy godmother and some animals and Aurora is protected by three fairy godmothers. All of these princesses have rival women who want to nullify their existence. In Branca de Neve this figure is represented by her stepmother, in Cinderella by her stepmother and their respective daughters, while in Aurora this figure is presented by Malévola (Fossatti, 2009). In Snow White, according to Breder:

"beware of the house a way of expressing gratitude to the dwarves for letting it hide in its house in the middle of the forest since its stepmother is looking for it to kill it. She cooks, sweeps, washes dishes, among other tasks, showing satisfaction. It is a clear reflection of the idea of "ideal woman (...)" (Breder, 2013, p.34).

Breder also states that "Cinderella, however, behaves quite differently. For her, housework is a terrible obligation imposed as a punishment by her stepmother"(Breder, 2013, p. 34). Silva \& Figueiredo consider that Aurora "wants to meet that special person and discover the wonders of true love" (Silva \& Figueiredo, 2016, p.4). Important social changes, evidenced by the role of women in society, were gaining evidence. The princesses followed these changes, without losing the magic and enchantment that we are used to in fairy tales (Fossatti, 2009). In this sense, a new group of princesses appears, the rebel princesses (1989-1998). Within this group, we can name several characters, such as Ariel, Bela, Jasmine, Pocahontas and Mulan. It is from this age that a change begins to exist. They are more active characters, there is a break in the rules imposed, courage and the search for independence are the qualities that stand out in view in the range of these princesses. There is a rupture in the role of caregiver of the home and family, becoming the protagonists of their own choices. Intelligent, adventurous, charming, strong and independent. According to Breder, "Ariel leaves the undersea kingdom and his family to discover the land of humans (... )" (Breder, 2017, p.35). While Bela:

“(...) She is passionate about books, Jasmine refuses to marry on her father's orders, Mulan dresses up as a man to go to war, Pocahontas faces the laws of his tribe and teaches a white man to respect 
nature. What they all bring in common are strong personalities, stories where they face the rules and change their destiny." (Breder, 2017, p.35).

As of 2009, the category for contemporary princesses emerges. Tiana, Rapunzel, Merida, Anna and Elsa are part of this core of princesses. In contrast, to what was observed in the first category of princesses, they do not need anyone to save them, being extremely independent. They classify themselves as curious, enterprising, strong, rebellious, fearless, adventurous, intelligent and self-possessed characters, managing to solve their problems. Tiana, from "Princess and the Frog", according to Silva "(..) is not a princess, she only becomes when she marries a prince. The character does not want to be a princess, instead she wants to open her restaurant" (Silva, 2016, p.92). Rapunzel, on the other hand, “(...) she doesn't dream of a prince, but of the lights that appear in the sky throughout her birthday, which is royalty dropping lanterns in honour of the lost princess, but she doesn't know that it is her" (Silva, 2016, p.99). The character Merida "(...) differs most from all the other princesses since she is the only one who was born a princess, but she doesn't want to be. She prefers to have the freedom to be stuck in a marriage arranged by her mother" (Silva, 2016, p.102). And finally, Anna and Elsa "(...) based on the relationship between them (...) the female relationship is the plot of the narrative without being represented by female rivalry and duality" (Silva, 2016, p.109). From Snow White to Anna and Elsa, we find that the characteristics of the princesses are constantly changing, as they follow the changes in society and their standards. To highlight what was mentioned earlier, we then analyzed the film "Brave".

\section{The new female image: analysis of the film narrative}

As previously mentioned, the character Merida from the film "Brave", came to revolutionize the paradigm of the characteristics that we all know about princesses. As Alves \& Nepomuceno affirm, "focus on the Merida character and her actions of breaking with the imagery of the classic princess" (Alves \& Nepomuceno, 2017, p.1). Released in 2012, "Brave", is considered by many authors to be a very surprising film, at different levels. For Alves \& Nepomuceno "Valente is not just another princess story of Disney studios, it is also a film made by Pixar, a renowned studio for the creation of new stories" (Alves \& Nepomuceno, 2017, p.1). Ferreira had considered:

“(...) Pixar's debut in the fairytale field, its first princess and also the studio's first female heroine. It is a contemporary princess, but still with much of what the collective imagination deposits in this figure. She is beautiful, like all her predecessors, but she is also questioning, rebellious, she does not like to comb her hair, wearing tight dresses, the "way of acting" of royalty and, above all, she does not dream of the en-sung prince." (Ferreira, 2015, p.44).

Carvalho considers the film "Brave":

“(...) Completely different from a traditional fairy tale, since the plot was created by the studio and not adapted. He was an Oscar winner for the best-animated feature of 2013. Still, it is the first one 
whose title does not correspond to the protagonist's name, however, it reflects her personality". (Carvalho, 2014, p.62).

The main character of the film, Merida, deserves special attention in this article, as she is a character who came to revolutionize the standard of traditional princesses. Merida lives with her parents, King Fergus and Queen Elinor and her brothers in the Scottish Highlands kingdom, DunBroch. According to Alves \& Nepomuceno:

"Merida identifies much more with the adventurous and free figure of the father than with the rule of the mother, always impeccable, with hair tied and following the rules of etiquette. Elinor has a serious and strong figure, being the real administrator of the kingdom. With all her diplomacy, she is the most respected one and listened to." (Alves \& Nepomuceno, 2017, p.4)

She is the first Disney princess to have a complete family, given that the previous princesses were orphans, raised by their stepmothers or did not have one of the family figures, maternal or paternal. Ferreira says that in the film "Valente":

"There is a loving family environment, the protagonist is not alone and needs to be helped by some stranger who will become her suitor to solve problems or reach a goal. If in the ten films that preceded the protagonists, they had no family or needed to break up with them to pursue their dream (...), Valente's central question is exactly the importance of keeping the family together." (Ferreira, 2015, p. 52).

Princess Merida is characterized by her long, tousled and crumbling hair, white skin, her face is rounded, with thick eyebrows and blue eyes. The princess does not value issues related to beauty and is accompanied, in most cases, with her bow and arrow. Ebersol considers Merida's hair (...)

"an important representation of your identity. The red colour is warm and is associated with the feeling of passion, energy, vitality and strength. The curly, bulky and undisciplined hair represents rebellion, transgression and insubmission, and also enunciates the character's search and appreciation for freedom." (Ebersol, 2014, p.4)

Merida is considered to be determined to travel her destiny, regardless of the traditions of her kingdom and, above all, her adventurous and courageous mother's plans. Its simplicity draws attention throughout the film, through its facial expressions. She has been an archer since she was little, and decides to fight her tradition, constantly causing her to conflict with her mother. She presents herself as a princess who breaks with this princess-stereotype waiting for the prince charming and looking for a female identity, regardless of imposed socio-cultural standards (Ebersol, 2014). Princess Merida, according to Ebersol: 
“(...) It deconstructs the role of a passive princess waiting for the prince who will lead her to her destiny when she makes Merida the active subject of the film and addresses the princess's representation when she questions and breaks with the destiny that would be imposed on her." (Ebersol, 2014, p.2).

And Ebersol, also states "When Merida breaks with her traditional destiny, she is breaking with the very impositions of gender roles in which women are subjected within their culture and their time" (Ebersol, 2014, p.4 ). The beginning of the film comes when the bear eats the leg of King Fergus, the characters who are in the camp are in danger, with the women fleeing and the men remaining to face the battle. Carvalho considers that it is from this scene that the film "Brave":

“(...) Starts to be narrated by Merida herself. The main point of his speech, unlike the previous ones where people talked about love, is destiny. Then, the character begins to describe her life as a princess, so there is no longer the voice of the narrator off who tells the story." (Carvalho, 2014, p.64).

The plot of the film is based on the conflicting relationship between Merida and her mother, in which Merida does not accept anyone's orders and wants to be free, while her mother represents a range of women who wait for male rules. On the other hand, there are scenes in the film in which Merida appears to use her bow in the forest, a behaviour that the mother condemns, as she considers it to be a male activity (Silva, 2016). In the scene where Queen Elinor informs her daughter about the clans' competition for her conquest, Merida imposes herself, saying that this is not what she wants for her life. We find that in this discussion, both have different perceptions concerning life, and Merida is not passive to her mother's determinations, exposing her opinion strongly. In the scene in which the clans go to the kingdom to win the hand of the princess, we can consider that it is another scene in which the difference between the two characters is strongly present. Elinor prepares her daughter for the games, being forced to wear a tight blue dress and put on a cap to hide her hair. To win the hand of the princess, the princes must hit the target, but in this scene, Merida decides to dispute her future. In this sense, Merida loosens her hair and tears the dress, being ready to hit all targets. It is clear in this scene that the princess once again challenges her own mother's rules (Silva, 2016).

We found that when the princess shoots the last arrow, she gets hurt in the face. At no time do we see Merida complaining about what happened, what worries only the character is the fact that her freedom is the cause. Merida's mother, indignant and disgusted by her daughter's attitude, pull her by the arms to the bedroom. At this moment, both characters present their ideas, and Merida does not accept her mother's ideals. Disgusted with the situation, it destroys the tapestry with the image of her family, this attitude is justified by the fact that the princess has lost her freedom. Queen Elinor, disgusted with her attitude, grabs her by the arms, takes the bow from her back and throws it into the fireplace. Disappointed and disgusted with everything that happened there, Merida went out riding through the forest crying (Carvalho, 2014). The main character, to regain her freedom, needs to change her mother's thinking. She uses a witch who asks for a spell in exchange for a necklace to transform her thought. The witch 
hands the princess a decorated cake. According to Carvalho "(...), a character requested a spell, while in previous films, the spell was cast on the characters against two wishes, in the form of punishment by an evil witch" (Carvalho, 2014, p.69).

Merida returns to the castle and hands the cake to her mother, as a way to apologize. The queen is surprised by her daughter's gesture since she does not know how to cook, but despite this, Elinor eats the bewitched cake. Merida verifies that the spell ends up not working because the queen turns into a bear. Carvalho considers that "(...) the figure of the witch, which leads us to classify the narrative as a fairy tale, because of its magical character. However, the witch in question does not want to be recognized as such"(Carvalho, 2014, p. 69). Merida and her mother decide to flee to the forest, given that King Fergus is traumatized by bears. It is from this scene that the film, in Silva's opinion "(...) begins to change the direction of the relationship between the two. Because when they try to undo the spell, they end up getting closer, understanding and learning from each other. That is, it is when the female friendship bond happens" (Sil-va, 2016, p.106). Through contact with nature, Queen Elinor loses her characteristics, as Carvalho says:

“(...) He ends up learning to fish and acts like a real bear, showing that the spell is taking over her. The delicate woman, concerned with the opinion of others, when she loses her beauty and sees herself transformed into an animal, is no longer concerned with showing her royalty and behaves according to her instincts. She is slowly transforming her way of thinking, apprehending that her attachment to good habits is not as essential for her life as she once thought" (Carvalho, 2014, p.70).

To break the spell, the two end up discovering that they have to sew the rug that Merida tore up in the argument that both had, for such Merida and her mother go to the castle. Although Merida sews the rug, the spell does not break and Queen Elinor does not return to her normal state. When the princess and the queen arrive at the castle, the clans continue to fight, since it is the image intended for them, throughout the film. Merida speaks in front of the men, apologizing. Observing the daughter's attitude, the queen, helps her to reformulate her speech, saying that each one is free to choose his destiny. Carvalho considers that it is from this scene that it becomes clear:

“(...) Transformation of values that occurred with the queen after going through adversities that she was not used to in her time as royalty. He realized, when living another reality, that there are other values and qualities as or even more important than what he defended during his life as a wife, mother and queen." (Carvalho, 2014, p.71).

After this scene, the queen flees into the forest, as she is pursued. Merida is trapped in her room, but with the help of her brothers, she manages to escape to the forest. With this attitude Merida, she is courageous again, since she will find solutions so that her mother's spell is not eternal. (Carvalho, 2014). We find that when the bear appears, Elinor gains the courage to defeat him and protect his family, being the only character who can defeat him. When the spell is broken and the queen becomes a woman again, we can verify the queen's changes, not only because of 
her attitudes but also physically. As Carvalho says "She is physically changed. Before, she always had her hair up and had a posture worthy of a classic queen. In the following scenes, he appears with loose hair, riding through the fields with his daughter (...)" (Carvalho, 2014, p.71). The "Valente" film ends with uncertainties regarding Merida's future, allowing each one to analyze the way they want. His fate is uncertain, there is no certainty whether the character meets his prince charming, as in previous cinematographies. We conclude that Merida is a princess with values contrary to the princesses that were analyzed, in the first part. The characteristics of this, refer to the third generation of princesses, as has also been analyzed. His courage, adventurous spirit and the search for his freedom are the characteristics that stand out most insight. The search for freedom predominates in all scenes of the film, Merida obtains her freedom, and the queen also manages to free herself from her character, modifying her ideals.

\section{Conclusion}

According to Carvalhal, the term Comparative Literature "(...) designates a form of literary research that confronts two or more pieces of literature" but, when we start to make contact with works classified as "comparative literary studies", we realize that this de-nomination ends up labelling very varied investigations, that adopt different methodologies and that, due to the diversification of the objects of analysis, grant to the compared literature a vast field of action (Carvalhal, 2006, p.5).

In this sense, this article starts from the objective of comparatively analyzing the traditional female portrait and the new female portrait. Children's Literature, namely fairy tales, found in cinema a new way of exposing their stories, as stated by Borges:

"The use of text adaptation in different media is not a recent phenomenon, but literature finds a new form of exposure in cinema and, in literature, it is in the line of research of comparative literature that studies on adaptation gain space." (Borges, 2013, p.168)

The works used for some of Disney's creations come from the adaptation of fairy tales, and these stories are part of society's discourse and refer to representations of concepts, according to Both " (...) the tales of fairies are works resulting from a certain historical and ideological context (...)" (Both, 2017, p.47). In agreement with Carvalho:

“(...) Fairy tales and animated cinema, not only help young people and children to reflect on the world around them but also help adults to enrich themselves socially and psychologically. Its social importance goes beyond the entertainment of the big screen." (Carvalho, 2014, p.80)

The study of the female character portrays her evolution over time, which can be understood through her discourse, influenced by social changes, beauty being an increasingly less important element, valuing the autonomy and independence of the female character. Through the analysis of the female character, which is presented in fairy tales and Disney productions, we can divide the princesses into three categories: classic princesses, rebel 
princesses and contemporary princesses. Classical princesses (1937-1959) are characterized by being innocent, tender, delicate and fragile, with the stereotype of housewives being associated with these princesses, in which their only concern is taking care of their children and the house. They want to find your love. As Lopes states:

“(...) The classic princesses are exalted, idolized women, idealized by men according to the profile "wife-mother-housewife", whose only objective is to find true love and, from there, dedicate herself to her only reason of living: taking care of the husband, the children and the family's happiness.."(Lopes, 2016, p.42)

The second category is characterized by a rupture of what was observed previously, in agreement with Lopes:

“(...) Change (...) explained by the change in values promoted with the development of the consumer society. Establishing a new culture that valued individual happiness, these new values disqualified the old stereotype of women in the home and ensured a new female social model that no longer depends on the traditionalist influence of men." (Lopes, 2016, p.44)

In the latter category, princesses are extremely independent, adventurous and courageous, according to Lopes "Contemporary princesses are independent, certain of who they are and their goals" (Lopes, 2016, p.47). Giving relevance to the analysis that was made, we can include the character, Merida, from the movie "Brave", in the category of contemporary princesses. She is the first princess who has a complete family and does not wait for the Prince Charming to be happy. Merida is brave, heroic, determined and independent. According to Alves \& Nepomuceno:

“(...) Disney / Pixar created the first feminist princess who, with a complete family, did not have to wait for the figure of a saving prince or have him as a final "gift" for eternal happiness. Co-angry and grounded in reality, Merida is brave, heroine, much more "human" and brave." (Alves \& Nepomuceno, 2017, p.10).

"Brave" confirmed that society is constantly changing, and that cinema follows this same evolution. It reflects how the female character was able to conquer her position over time, and how she achieved her independence, ceasing to be dependent on the male figure.

\section{References}

Aguiar, E. \& Barros, M. (2015). A Representação Feminina nos Contos de Fadas das Animações de Walt Disney: a Ressignificação do Papel Social da Mulher. XVII Congresso de Ciências da Comunicação na Região Nordeste-Natal-RN. http://www.portalintercom.org.br/anais/nordeste2015/resumos/R47-1959-1.pdf 
Alves, L. \& Nepomuceno, M. (2017). Uma valente análise semiótica: a desconstrução e humanização da Princesa Merida. 40ํㅡㄹ Congresso Brasileiro de Ciências da Comunicação: Curitiba. http://portalintercom.org.br/anais/nacional2017/resumos/R12-2086-1.pdf

Borges, S. (2013). Literatura Comparada e adaptação cinematográfica: a marcha de soldados de Salamina. Caderno Seminal Digital, 20(20), p. 162-185. https://www.epublicacoes.uerj.br/index.php/cadernoseminal/article/view/12020/9407

Both, L. (2017). As representações identitárias de gênero nas animações cinematográficas dos contos de fadas. (Dissertação de Mestrado, Universidade do Vale do Rio dos Sinos: São Leopoldo). Disponível em: http://www.repositorio.jesuita.org.br/bitstream/handle/UNISINOS/7379/Luciane\%20Ma ria\%20Both.pdf?sequence $=1 \&$ isAllowed $=y$

Breder, F. (2013). Feminismo e príncipes encantados: a representação feminina nos filmes de princesa da Disney. (Dissertação de Mestrado, Universidade Federal do Rio de Janeiro). Disponível em: https://literaturaexpandida.files.wordpress.com/2011/09/feminismo-eprc3adncipes-encantados-a-representac3a7c3a3o-feminina-nos-filmes-de-princesa-dadisney.pdf

Carvalhal, T. (2006). Literatura Comparada. Revista e ampliada, 4.ed. São Paulo: Ática. https://rl.art.br/arquivos/6175748.pdf?1517569757

Carvalho, A. (2014). Personagens femininas em animações dos estúdios da Disney: transformações de perfis em mulheres complexas. (Dissertação de Mestrado, Universidade Federal do Rio Grande do Sul: Porto Alegre). https://www.lume.ufrgs.br/bitstream/handle/10183/103387/000932660.pdf?sequence=1\& isAllowed $=\mathrm{y}$

Coutinho, F, E. (2006). Literatura Comparada: reflexões sobre uma disciplina académica. Revista Brasileira de Literatura Comparada, 8(8), p. 42-44. http://revista.abralic.org.br/index.php/revista/article/view/113/114

Ebersol, I. (2014). Merida e as imposições de gênero: uma análise de costrução visual da personagem Valente. III Seminário Nacional de Educação, Diversidade Sexual e Direitos Humanos.

Vitória, Brasil. http://www.2014.gepsexualidades.com.br/resources/anais/4/1405565841 ARQUIVO M ERIDAEASIMPOSICOESDEGENEROUMAANALISEDACONSTRUCAOVISUALDAP ERSONAGEMDEVALENTE.pdf

Ferreira, J. (2015). Mérida e Elsa: as princesas do século XXI. (Dissertação de Mestrado, Universidade Federal do Rio de Janeiro). https://pantheon.ufrj.br/bitstream/11422/4646/1/JFerreira.pdf

Fossatti, C. (2009). Cinema de animação e as princesas: Uma análise das categorias de gênero. X Congresso de Ciências da Comunicação na Região Sul-Blumenau: Porto Alegre. http://intercom.org.br/papers/regionais/sul2009/resumos/R16-0120-1.pdf

Freire, F. (2008). Literatura e adaptação cinematográfica: diferentes linguagens, diferentes leituras. Soletras, (15), 179-186. publicacoes.uerj.br/index.php/soletras/article/view/4869/3599 
Guerreiro, C. (2013). Os contos da infância e do lar: da tradição oral à literatura para a infância. Revista Álabe, no8, p. 1-12. http://revistaalabe.com/index/alabe/article/view/160

Lima, I., Antunes, A. \& Pereira, C. (2018). Espelho, espelho meu...: representação feminina e redesign das princesas dos filmes da Disney. 41ํㅡㄹ Congresso Brasileiro de Ciências da Comunicação: Joinville. http://portalintercom.org.br/anais/nacional2018/resumos/R13$\underline{\text { 0554-1.pdf }}$

Lopes, K. (2015). Análise da evolução do estereótipo das princesas Disney. (Dissertação, Centro Universitário de Brasília - Faculdade de Tecnologia e Ciências Socias Aplicadas). https://repositorio.uniceub.br/jspui/bitstream/235/7620/1/20977757.pdf?fbclid=IwAR20G 6OaKTbv--V6jfbYDzwbqQRnM-XpmhOJF1M2nIAJBkDISLY2BGuzmLQ

Maia, R. \& Maia, C. (2015). Os contos de fadas no cinema: uma perspectiva das construções de gênero, sua história e transformações. Revista Ágora, (22), p. 258-274. https://periodicos.ufes.br/agora/article/view/13621

Pihel, R. (2013). Uma Proposta de Tradução de Contos de Fadas de Hermann Hesse num Modelo de Edição Bilingue. (Dissertação de Mestrado, Universidade de Lisboa). https://repositorio.ul.pt/bitstream/10451/10054/1/ulfl146003 tm.pdf

Silva, A. \& Figueiredo, C. (2016). Valente e a construção arquetípica da princesa nas narrativas Disney. XVIII Congresso de Ciências da Comunicação na Região Nordeste - Caruaru PE. http://www.portalintercom.org.br/anais/nordeste2016/resumos/R52-0523-1.pdf

Silva, C. (2016). A leitura dos contos de fada e sua influência na formação e educação da criança pré-escolar nos centros municipais de educação infantil no município do Recife-PE. ACADEMO Revista de Investigación en Ciencias Sociales y Humanidades, 3(1), p. 1-17. https://revistacientifica.uamericana.edu.py/index.php/academo/article/view/40/38

Silva, I. (2016). Sororidade e rivalidade feminina nos filmes de princesa da Disney. (Dissertação de Mestrado, Universidade de Brasília). https://bdm.unb.br/bitstream/10483/16599/1/2016 IvanaCarolinaSilva tcc.pdf 
Author(s) will retain the copyright of their published articles agreeing that a Creative Commons Attribution 4.0 International License (CC BY 4.0) terms will be applied to their work. Under the terms of this license, no permission is required from the author(s) or publisher for members of the community to copy, distribute, transmit or adapt the article content, providing a proper, prominent and unambiguous attribution to the authors in a manner that makes clear that the materials are being reused under permission of a Creative Commons License. Views, opinions and conclusions expressed in this research article are views, opinions and conclusions of the author(s). and European Journal of Literature, Language and Linguistics Studies shall not be responsible or answerable for any loss, damage or liability caused in relation to/arising out of conflicts of interest, copyright violations and inappropriate or inaccurate use of any kind content related or integrated into the research work. All the published works are meeting the Open Access Publishing requirements and can be freely accessed, shared, modified, distributed and used in educational, commercial and non-commercial purposes under a Creative Commons Attribution 4.0 International License (CC BY 4.0). 